MEL WESTERMAN

\title{
Salary Comparisons between Academic Librarians and Instructional Faculty
}

\section{INTRODUCTION}

The faculty status of librarians in institutions of higher education is often discussed in terms of the responsibilities, privileges, benefits, and compensations of instructional faculty. Salaries have been compared in a variety of ways and at a number of levels. One popular basis for analyses of salaries has been the responses to questionnaires mailed by researchers. These analyses are constrained by the objectives and funds of the researchers and the quality and quantity of the responses. A method of statistical analysis of salaries on a national scope is needed as a standard basis for comparison.

Salaries of librarians at institutions of higher education have been surveyed and reviewed many times. Because each survey has its own objectives and methods of compilation and analysis, comparisons between surveys become problematical. Problems become more perplexing when comparisons between librarians and instructional faculty are attempted. The publication of salary comparisons between academic librarians and instructional faculty by Anita R. Schil$\operatorname{ler}^{1}$ in 1969 and the results of the happenings at the Atlantic City Annual Conference of the American Library Association that year legitimatized comparisons between the salaries of these two professions. The "Standards for Faculty Status for College and University Librarians,"2 adopted by the membership of the ACRL in 1971, states: "The salary scale for librarians should be the same as that for other academic categories with equivalent education and experience." 3

In his review of the "progress toward faculty status" between 1969 and 1979, R. Dean Galloway "sought opinions from librarians who had been involved in the faculty status

Mel Westerman is a senior assistant reference librarian specializing in business, and a master'sdegree candidate in public administration, University Libraries, Pennsylvania State University, University Park. movement at Atlantic City." He also cites a number of studies, reviews librarians' qualifications and collective bargaining, and briefly touches on salaries and other benefits. ${ }^{4}$ His comments on salaries are only summary in nature, but he mentions a source for data that has the potential to develop, by statistical techniques, into valid comparisons between librarian and instructional faculty salaries.

The salary data cited by Galloway are reported by the American Association of University Professors (AAUP). The AAUP data are national in scope, a scope sufficiently broad for the analyses of statistical associations. This scope overcomes much of the perplexities of analyses based on various surveys that have different objectives and methods of compilation.

The data avoid the unresolved issues of the meanings of faculty status for librarians and the "equivalent education and experience" called for in the ACRL "Standards." Academic librarians are compared with academic instructional faculty on an equivalent basis. The data in the format presented by the AAUP can be transformed for comparison purposes. The AAUP also uses the same data in comparisons of instructional faculty salaries to other salary scales, such as that of government service.

\section{METHOD}

The AAUP tabulations for instructional faculty salaries were based on data for 2,652 institutions of higher education. They were weighted average salaries for full-time faculty on a standard academic-year basis for $1977-78 .^{5}$ They were from the 1977-78 "Annual Report of Committee $\mathrm{Z}$ on the Economic Status of the Profession," compiled by Maryse Eymonerie, (then) associate secretary for research of the AAUP. The data were originally collected by the National Center for Educational Statistics (NCES) through their Higher Education General Information Survey (HEGIS XII). ${ }^{6}$ 
The AAUP tabulations for librarians were based on data for 1,557 institutions. They were weighted average salaries for full-time library staff on a twelve-month basis for 1977-78 prepared by the AAUP Committee $\mathrm{Z}$ Washington Office staff from a data tape obtained from the NCES library branch. ${ }^{7}$

The categories of institutions were defined by the AAUP as follows:

Category $I$-includes institutions that offer the doctorate degree and which conferred in the most recent three years an annual average of fifteen or more earned doctorates covering a minimum of three nonrelated disciplines.

Category IIA-includes institutions awarding degrees above the baccalaureate but not included in category one.

Category $I I B$-includes institutions awarding only the baccalaureate or equivalent degree.

Category III-includes two-year institutions with academic ranks.

A fourth category used by the AAUP was deleted from the present study because data items were insufficient for meaningful analyses. The NCES did not release salary data in cells with one or two individuals. Thus, a number of libraries submitting data were not included in the tabulations. Because of the deletion of the fourth category, averages for all categories combined for each academic rank or library position were not possible. The combination of all types of institutions (public, private, and church related) were possible within the two full categories and two subcategories.

The library position levels of technical, clerical, and other supporting staff were deleted from the AAUP data because these could not be considered faculty level positions. In most types of institutions, Other Professionals would not be considered faculty. They were included in the tabulations to add balance, but were dropped from some of the analyses.

The present methodology included the levels of the standard academic ranks of Professor, Associate Professor, Assistant Professor, and Instructor, with three library position levels of Chief, Deputy, Associate, and Assistant Chief Librarians; All Other Librarians; and Other Professionals. All of the seven levels were tabulated with the three types of in- stitutions, and all three were combined under each category and subcategory to produce table 1 .

The tabulations in the academic rank columns of table 1 were each multiplied by eleven-ninths (11/9). This transformation compensated for the differences between the number of months worked each year by instructional faculty and librarians. Although the AAUP reported a twelve-month basis for library staff salaries, it is not uncommon for librarians at institutions of higher education to receive one month of vacation annually. The salaries of instructional faculty were reported by the AAUP on a "standard academic-year basis." The tabulations resulting from the transformation for number of months worked each year clearly showed that Professor and Category I salaries were the highest.

To establish scaled relationships between Professor salaries and other salaries in each type of institution, the Professor salaries were set at 100. By dividing each Professor salary into 100 and multiplying the product times each of the other salaries, relative (scale) values were produced for each type of institution. $[(100 \div$ Professor Salary $) \times$ (Other Salary $)=$ scale value.]

Because the All Combined salaries line for types of institutions within categories were unaffected by earlier data deletions, the same transformations were applied to them. The values in the All Combined line of Category I institutions were each set at 100 .

By dividing the All Combined values into 100 , ratios were established. These ratios were then multiplied by the All Combined salaries in each category below them to produce the ${ }^{*}$ All Combined values. $[(100 \div$ Category I All Combined value) $\mathrm{x}$ (other category All Combined value) $={ }^{*}$ All Combined value.] The results of the above two transformations are shown in table 2.

The percentages in table 2 are relative magnitudes only. Professors obviously do not earn all there is to earn, nor do they earn the highest possible salary. Use of the definition of percentages that refers to parts and a whole would lead to misinterpretation of table 2. Misinterpretation should be avoided by recognizing that the other salaries are represented in terms relative to the highest level. Thus, the figures in the cells of the lines to the 
right of the $100 \mathrm{~s}$ are scale values relative to Professors being 100. Likewise, the ${ }^{*}$ All Combined lines have figures in the cells that are scale values relative to the Category I All Combined values at the tops of the columns. The use of percentages in table 2 to scale the salary data allows the relationships of the values to be understood and referenced in simple terms.

To identify the equivalent salary levels by types of institutions within categories, groups within five percentage points were produced. This resulted in five or six groups for each type of institution. These groups were usually separated by more than five percentage points. The distances between groups were not represented in the tabulations. (See table 3.)

This transformation of the data revealed that all academic librarian salary groups were below the highest-level salary group of instructional faculty (Professors). Levels of librarians' salary groups shift downward on the instructional faculty scale in the highernumbered categories of institutions. The highest-level salary group of librarians is even below the lowest level of instructional faculty in Category III.
To help clarify the array of librarians' salary groups within instructional faculty salary groups in table 3 , table 4 was compiled. Table 4 shows the spreads between the lowest and highest instructional faculty salaries and between Chief and Other Librarians based on the percentages in table 2 . In table 4 the general trend in the narrowing of spread of instructional faculty salaries is reflected in a narrowing of librarian salaries. This is as would be expected. Not necessarily to be expected, though, is that by comparison of table 4 and table 3 it can be seen that narrower spreads of instructional faculty salaries are directly related to library salaries being in lower groups.

The spread of salary data for librarians is narrow compared to the spread of instructional faculty salaries. The widest spread between the lowest instructional faculty percentage (Instructor) and the highest (Professor) is 54.33 percent. The widest spread between percentages for Other Librarians and Chief Librarians is 26.54 percent. The difference between these two spreads $(54.33 \%-26.54 \%=27.79 \%)$ is greater than the spread of the librarian percentages. The narrowest spread in instructional fac-

TABLE 1

INSTRUCTIONAL FACULTY AND LIBRARIAN SALARIES BY TYPES OF INSTITUTIONS

\begin{tabular}{|c|c|c|c|c|c|c|c|}
\hline & Professors & $\begin{array}{c}\text { Chief } \\
\text { Librarians }\end{array}$ & $\begin{array}{l}\text { Associate } \\
\text { Professors }\end{array}$ & $\begin{array}{c}\text { Other } \\
\text { Librarians }\end{array}$ & $\begin{array}{l}\text { Assistant } \\
\text { Professors }\end{array}$ & $\begin{array}{c}\text { Other } \\
\text { Professionals }\end{array}$ & Instructor: \\
\hline \multicolumn{8}{|l|}{ Category I } \\
\hline Public & 26,420 & 24,450 & 19,780 & 15,880 & 16,090 & 12,620 & 12,860 \\
\hline Private Independent & 28,880 & 23,210 & 20,150 & 14,820 & 16,140 & 12,470 & 13,190 \\
\hline Church-Related & 24,850 & 18,850 & 19,320 & 12,870 & 15,920 & 12,440 & 12,640 \\
\hline All Combined & 26,880 & 23,210 & 19,810 & 15,380 & 16,090 & 12,570 & 12,890 \\
\hline \multicolumn{8}{|l|}{ Category IIA } \\
\hline Public & 24,290 & 19,700 & 19,280 & 15,900 & 15,860 & 11,610 & 12,790 \\
\hline Private Independent & 23,380 & 17,050 & 18,470 & 13,210 & 15,130 & 9,380 & 11,960 \\
\hline Church-Related & 19,950 & 14,240 & 16,550 & 11,980 & 14,040 & 8,180 & 11,160 \\
\hline All Combined & 23,690 & 18,070 & 18,870 & 15,190 & 15,550 & 10,850 & 12,480 \\
\hline \multicolumn{8}{|l|}{ Category IIB } \\
\hline Public & 22,070 & 17,730 & 18,060 & 14,720 & 15,220 & 9,710 & 12,470 \\
\hline Private Independent & 21,790 & 14,390 & 16,650 & 12,440 & 13,830 & 8,370 & 11,360 \\
\hline Church-Related & 18,560 & 12,430 & 15,290 & 11,360 & 12,960 & 7,990 & 10,740 \\
\hline All Combined & 20,400 & 14,070 & 16,390 & 13,140 & 13,790 & 8,620 & 11,400 \\
\hline \multicolumn{8}{|l|}{ Category III } \\
\hline Public & 23,240 & 18,720 & 19,360 & 17,590 & 16,220 & 14,440 & 13,990 \\
\hline Private Independent & 15,560 & 11,350 & 14,660 & 12,280 & 12,380 & - & 11,100 \\
\hline Church-Related & 13,470 & 13,750 & 13,100 & 12,730 & 12,030 & - & 9,480 \\
\hline All Combined & 22,780 & 18,470 & 19,120 & 17,490 & 16,030 & 14,440 & 13,790 \\
\hline
\end{tabular}

Category I - includes institutions which offer the doctorate degree and which conferred in the most recent three years an annual average of fifteen or more earned doctorates covering a minimum of three nonrelated disciplines.

Category IIA - includes institutions awarding degrees above the baccalaureate but not included in Category I.

Category IIB - includes institutions awarding only the baccalaureate or equivalent degree.

Category III - includes two-year institutions with academic rank.

Sources: AAUP Bulletin 64:197 (Sept. 1978); and Academe 12, no. 4:8 (Dec. 1978). 
TABLE 2

SCALEd Instructional Faculty and Librarian SALARIES BY Types of InStitutions

\begin{tabular}{|c|c|c|c|c|c|c|c|}
\hline & Professors & $\begin{array}{c}\text { Chief } \\
\text { Librarians }\end{array}$ & $\begin{array}{l}\text { Associate } \\
\text { Professors }\end{array}$ & $\begin{array}{c}\text { Other } \\
\text { Librarians }\end{array}$ & $\begin{array}{l}\text { Assistant } \\
\text { Professors }\end{array}$ & $\begin{array}{c}\text { Other } \\
\text { Professionals }\end{array}$ & Instructors \\
\hline \multicolumn{8}{|l|}{ Category I } \\
\hline Public & 100.00 & 75.72 & 74.87 & 49.18 & 60.90 & 39.08 & 48.68 \\
\hline Private Independent & 100.00 & 65.75 & 69.77 & 41.99 & 55.89 & 35.33 & 45.67 \\
\hline Church-Related & 100.00 & 62.06 & 77.75 & 42.37 & 64.07 & 40.96 & 50.87 \\
\hline All Combined & 100.00 & 70.65 & 73.70 & 46.81 & 59.86 & 38.26 & 47.95 \\
\hline "All Combined & 100.00 & 100.00 & 100.00 & 100.00 & 100.00 & 100.00 & 100.00 \\
\hline \multicolumn{8}{|l|}{ Category IIA } \\
\hline $\begin{array}{l}\text { Public } \\
\text { Private Independent }\end{array}$ & $\begin{array}{l}100.00 \\
100.00\end{array}$ & $\begin{array}{l}66.36 \\
59.67\end{array}$ & 79.00 & $\begin{array}{l}53.56 \\
46.23\end{array}$ & $\begin{array}{l}65.29 \\
64.71\end{array}$ & $\begin{array}{l}39.11 \\
32.82\end{array}$ & 52.65 \\
\hline Church-Related & 100.00 & 58.40 & 82.96 & 49.13 & 70.38 & 33.54 & 55.94 \\
\hline -All Combined & 88.13 & 77.85 & 95.25 & 98.76 & 96.64 & 86.32 & 96.82 \\
\hline \multicolumn{8}{|l|}{ Category IIB } \\
\hline Public & 100.00 & 65.73 & 81.83 & 54.57 & 68.96 & 36.00 & 56.50 \\
\hline Private Independent & 100.0 & 54.0 & 76. & 46. & 63. & 31. & 52.13 \\
\hline Church-Related & 100.00 & 54.8 & 82.38 & 50.08 & 69.83 & 35.22 & 57.87 \\
\hline $\begin{array}{l}\text { "All Combined } \\
\text { Category III }\end{array}$ & 75.89 & 60.62 & 82.74 & 85.44 & 85.70 & 68.58 & 88.44 \\
\hline Public & 100.00 & 65.91 & 83.31 & 61. & 69. & 50.84 & 60.20 \\
\hline Private Independent & 100.00 & 59.6 & 94.21 & 64.57 & 79.56 & - & 71.34 \\
\hline Church-Related & 100.00 & 83. & 97.25 & 77.32 & 89.31 & - & 70.38 \\
\hline •All Combined & 84.75 & 79.58 & 96.52 & 113.72 & 99.62 & 114.88 & 106.98 \\
\hline
\end{tabular}

Categories in this table are the same as in table 1.

The -All Combined line in each category allows comparisons between categories. The numbers in the cells of the ${ }^{*}$ All Combined lines have the same relationship to the "All Combined numbers in the Category I cells, as do the numbers for academic ranks and library positions to Professors.

ulty percentages is 28.66 percent. This is still wider than the widest spread in librarian percentages. The narrowest spread in librarian percentages is 3.98 percent.

\section{Conclusions}

Salary data that are broadly national in scope, though unbiased by the objectives and limitations of an individual researcher, do have some limitations. The number of institutions included in each of the two surveys used could be more equal. The salary levels for librarians could be redefined to produce four equivalents to the instructional faculty levels.

The AAUP conducted their first annual salary survey in 1958. They began to rely on the NCES for data collection in 1977. The instructional faculty salaries in this article are based on 2,652 institutions for the 1977-78 academic year. ${ }^{8}$ The librarian salary data used in this article are also for the 1977-78 academic year, but are based on 1,557 institutions. ${ }^{9}$ It is hoped that the number of institutions included will become more equal. The original number of institutions used by the NCES for the librarian salary data was 3,058 in 1977 . Some research on the transformation of the data from the NCES to the
AAUP publications would be of future interest.

The redefinition of salary levels for the librarians might be a less promising proposal. The present structure of Chief Librarians, All Other Librarians, and Other Professional Staff is the traditional classification, based on decades of library personnel practices. A reclassification should be considered, although it would cause a rift between academic librarians and librarians in other types of institutions. The academic librarian levels could be based on academic achievement (broadly defined), rather than on administrative position.

Although the NCES data has some limitations, the methodology used in this study puts the emphasis on comparisons that are often obscured by a multitude of considerations. For example, when debate about salaries begins to include the meaning of such statements as "equivalent education and experience," 10 the point of the equivalence of real salaries becomes confounded. The present data clearly shows that librarians are paid less than instructional faculty in all categories of institutions.

The numbers of institutions included in both data sets are large enough to be signifi- 
TABLE 3

Faculty Ranks and Librarian Positions Grouped by Percentage of Professors' Salaries

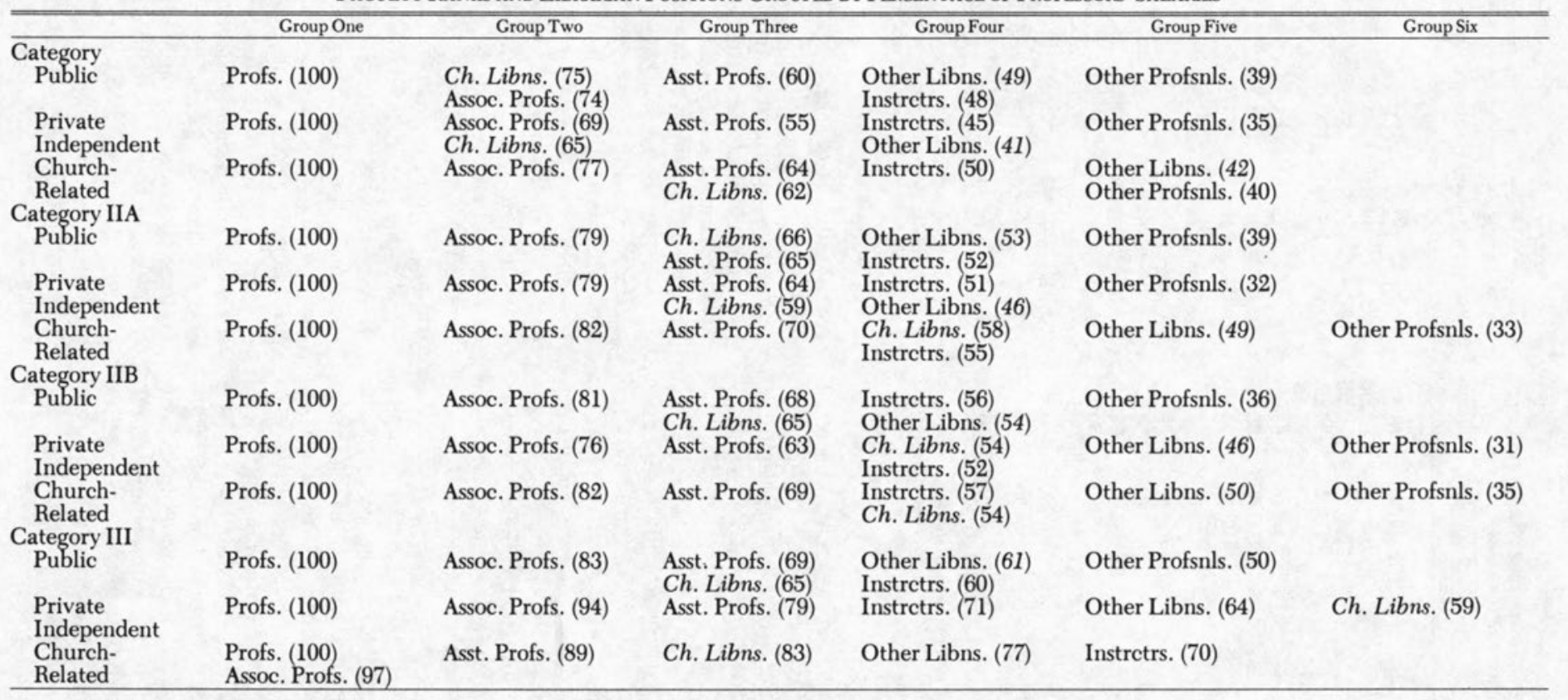

Categories in this table are the same as in table 1.

The position of Chief Librarians is set in italics for comparison, as is the percentage of Other Librarians in each line.

The numbers in parentheses are the scaled levels of the positions and ranks.

Groups are determined by positions and rank percentages being within five percentage points. There is no relative scale among groups. 
TABLE 4

SPREAd OF SCALED INSTRUCTIONAL FACULTY AND Libraruan Salaries

\begin{tabular}{|c|c|c|}
\hline & $\begin{array}{c}\text { Instructional } \\
\text { Faculty }\end{array}$ & Librarians \\
\hline \multicolumn{3}{|l|}{ Category I } \\
\hline Public & 51.32 & 26.54 \\
\hline $\begin{array}{l}\text { Private } \\
\text { Independent }\end{array}$ & 54.33 & 23.76 \\
\hline Church- & & \\
\hline $\begin{array}{r}\text { Related } \\
\text {. }\end{array}$ & 49.13 & 19.69 \\
\hline Category IIA & 47.35 & 12.80 \\
\hline Private & & \\
\hline $\begin{array}{l}\text { Independent } \\
\text { Church- }\end{array}$ & 48.85 & 13.44 \\
\hline Related & 44.06 & 9.27 \\
\hline \multicolumn{3}{|l|}{ Category IIB } \\
\hline $\begin{array}{l}\text { Public } \\
\text { Private }\end{array}$ & 43.50 & 11.16 \\
\hline $\begin{array}{l}\text { Private } \\
\text { Independent }\end{array}$ & 47.87 & 7.32 \\
\hline Church- & & \\
\hline Related & 42.13 & 4.72 \\
\hline \multicolumn{3}{|l|}{ Category III } \\
\hline $\begin{array}{l}\text { Public } \\
\text { Private }\end{array}$ & 39.80 & 3.98 \\
\hline $\begin{array}{l}\text { Private } \\
\text { Independent }\end{array}$ & 2866 & $(4,89)$ \\
\hline Church- & & \\
\hline Related & 29.62 & 6.20 \\
\hline
\end{tabular}

cant. The institutional categories match well. The AAUP uses the NCES data to compare instructional faculty salaries to four other professional groups. Their data display is based on salaries and is organized to avoid other considerations. ${ }^{11}$

A future study could compare librarians' salaries to the four groups used by the AAUP.
These are: (1) federal government; (2) private industry; (3) broad occupation groups; and (4) professional and managerial groups.

Although the present study presents data for direct comparison between instructional faculty and librarians, the data can be used to compare salaries among types of institutions and categories of institutions within the various levels of librarianship.

\section{REFERENCES}

1. Anita R. Schiller, “Academic Librarians' Salaries," College \& Research Libraries 30:101-11 (March 1969).

2. Association of College and Research Libraries, "Standards for Faculty Status for College and University Librarians," College \& Research Libraries News 33:210-12 (Sept. 1972).

3. Ibid., p.211.

4. R. Dean Galloway, "Status or Stasis: Academic Librarians 10 Years Later," American Libraries 10:349-52 (June 1979).

5. "Report on the Annual Survey of Faculty Compensation, 1977-78," AAUP Bulletin 64:197 (Sept. 1978).

6. Ibid., p.193-95.

7. "Library Staff Salaries," Academe 12, no.4:8 (Dec. 1978).

8. "Report on the Annual Survey," p.193-94.

9. "Library Staff Salaries," p.8.

10. Association of College and Research Libraries, "Standards," p.211.

11. "Annual Report on the Economic Status of the Profession, 1979-80," Academe 66:393 (Nov. 1980). 


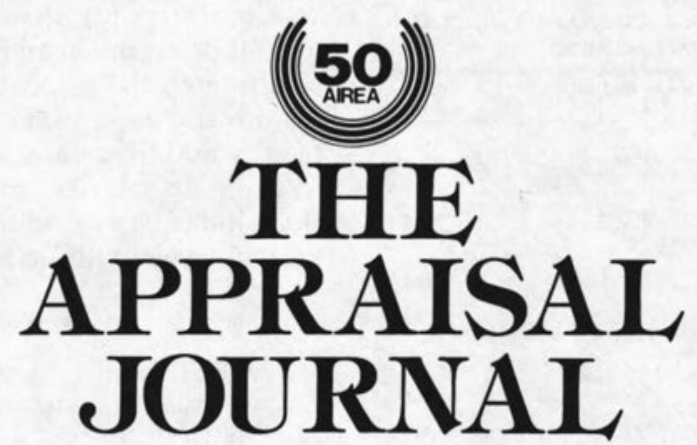

The members of the Appraisal Institute have, over the last fifty years, worked towards the development of a comprehensive body of knowledge in the field of real estate appraising. Based on experience and proven skills, that knowledge is shared with other professionals through publication of our quarterly Appraisal Journal.

A pioneer in appraisal publishing and education, the Institute is the oldest professional appraisal organization and the only one affiliated with the National Association of REALTORS ${ }^{\circledR}$. Its members hold the most sought after designations in appraising: MAI (Member, Appraisal Institute) and RM (Residential Member).

But our wealth of knowledge doesn't come from appraisers alone. The Journal publishes articles contributed by academicians and other experts in real estate-related fields. All articles are carefully researched and documented, and cover all aspects of appraisal practice ... to shed light on all aspects of real estate value.

In recent issues: "Appraising the Best Tax Shelter in History" "Valuation and Condominium Conversion"

"Measuring Energy Efficiency for Comparable Sales"

"Will People Move Back to the City?" "Valuation of Co-op Buildings"

Annual subscription: $\$ 25.00$ Foreign subscription: $\$ 27.00$

\section{THE APPRAISER}

To supplement the Journal, AIREA also publishes this 10-issue per year news bulletin covering real estate-related happenings and trends. Annual subscription: $\$ 10.00$ Write for a free sample copy of The Appraisal Journal. Binders and slipcases available at $\$ 8$ each.

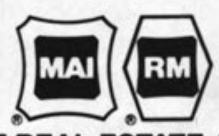

AMERICAN INSTITUTE OF REAL ESTATE APPRAISERS /Dept. C\&RL 430 N. Michigan Ave., Chicago, IL 60611 